Erratum

\title{
Erratum to "Inhibitory Effect of Long-Chain Fatty Acids on Biogas Production and the Protective Effect of Membrane Bioreactor"
}

\author{
Kris Triwulan Dasa, ${ }^{1}$ Supansa Y. Westman, ${ }^{2}$ Ria Millati, ${ }^{1}$ Muhammad Nur Cahyanto, ${ }^{1}$ \\ Mohammad J. Taherzadeh, ${ }^{2}$ and Claes Niklasson ${ }^{3}$ \\ ${ }^{1}$ Department of Food and Agricultural Product Technology, Universitas Gadjah Mada, Yogyakarta 55281, Indonesia \\ ${ }^{2}$ Swedish Center for Resource Recovery, University of Borås, 50190 Borås, Sweden \\ ${ }^{3}$ Department of Chemistry and Chemical Engineering, Chalmers University of Technology, 41296 Gothenburg, Sweden \\ Correspondence should be addressed to Ria Millati; ria_millati@ugm.ac.id \\ Received 19 October 2016; Accepted 27 October 2016
}

Copyright (C) 2016 Kris Triwulan Dasa et al. This is an open access article distributed under the Creative Commons Attribution License, which permits unrestricted use, distribution, and reproduction in any medium, provided the original work is properly cited.

In the article titled "Inhibitory Effect of Long-Chain Fatty Acids on Biogas Production and the Protective Effect of Membrane Bioreactor" [1], the word "stabil" is misspelled in section "3.2.2. Volatile Fatty Acid and pH." It should be corrected to "stable." In addition, the bar charts for the encased cell of Figure 3 are not clear. A clearer version can be found as follows.

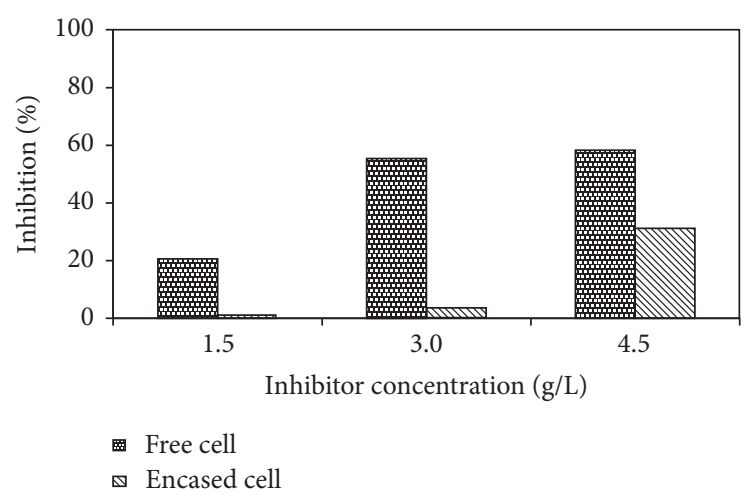

(a)

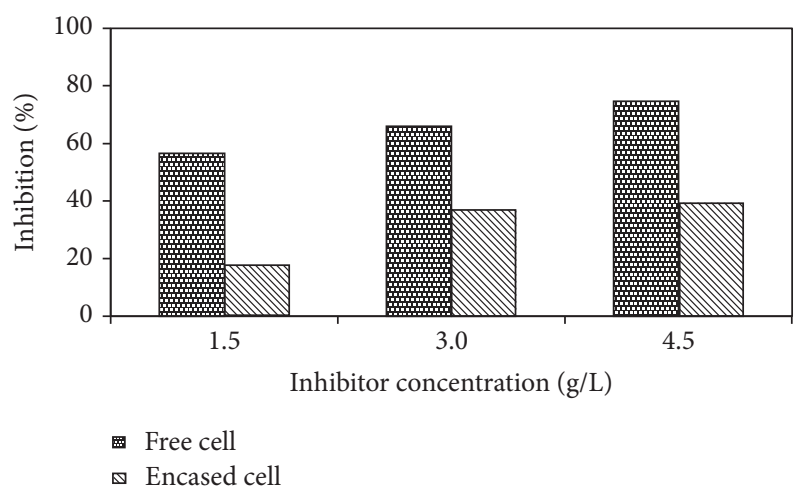

(b)

Figure 3: Continued. 


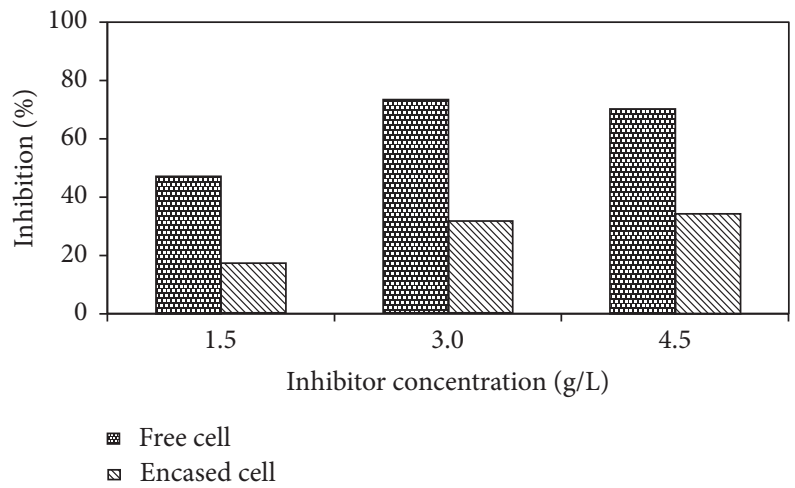

(c)

FIgURE 3: Percentage of inhibition in the reactors with the free cells and MBR with the encased cells in the presence of LCFAs. (a) Palmitic acid, (b) stearic acid, and (c) oleic acid.

\section{References}

[1] K. T. Dasa, S. Y. Westman, R. Millati, M. N. Cahyanto, M. J. Taherzadeh, and C. Niklasson, "Inhibitory effect of longchain fatty acids on biogas production and the protective effect of membrane bioreactor," BioMed Research International, vol. 2016, Article ID 7263974, 9 pages, 2016. 

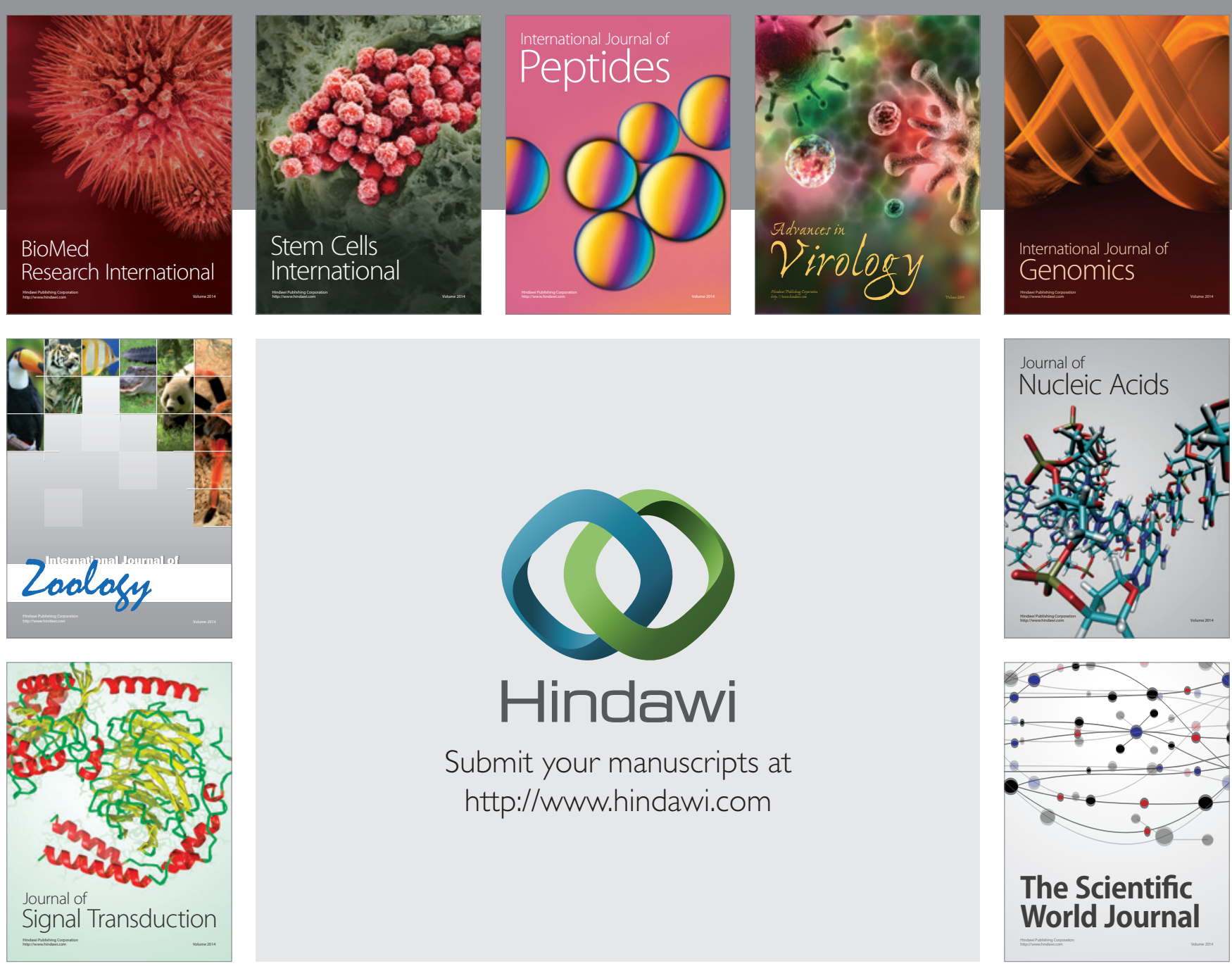

Submit your manuscripts at

http://www.hindawi.com
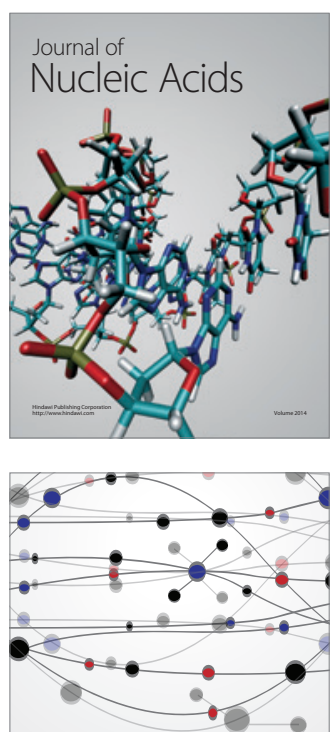

The Scientific World Journal
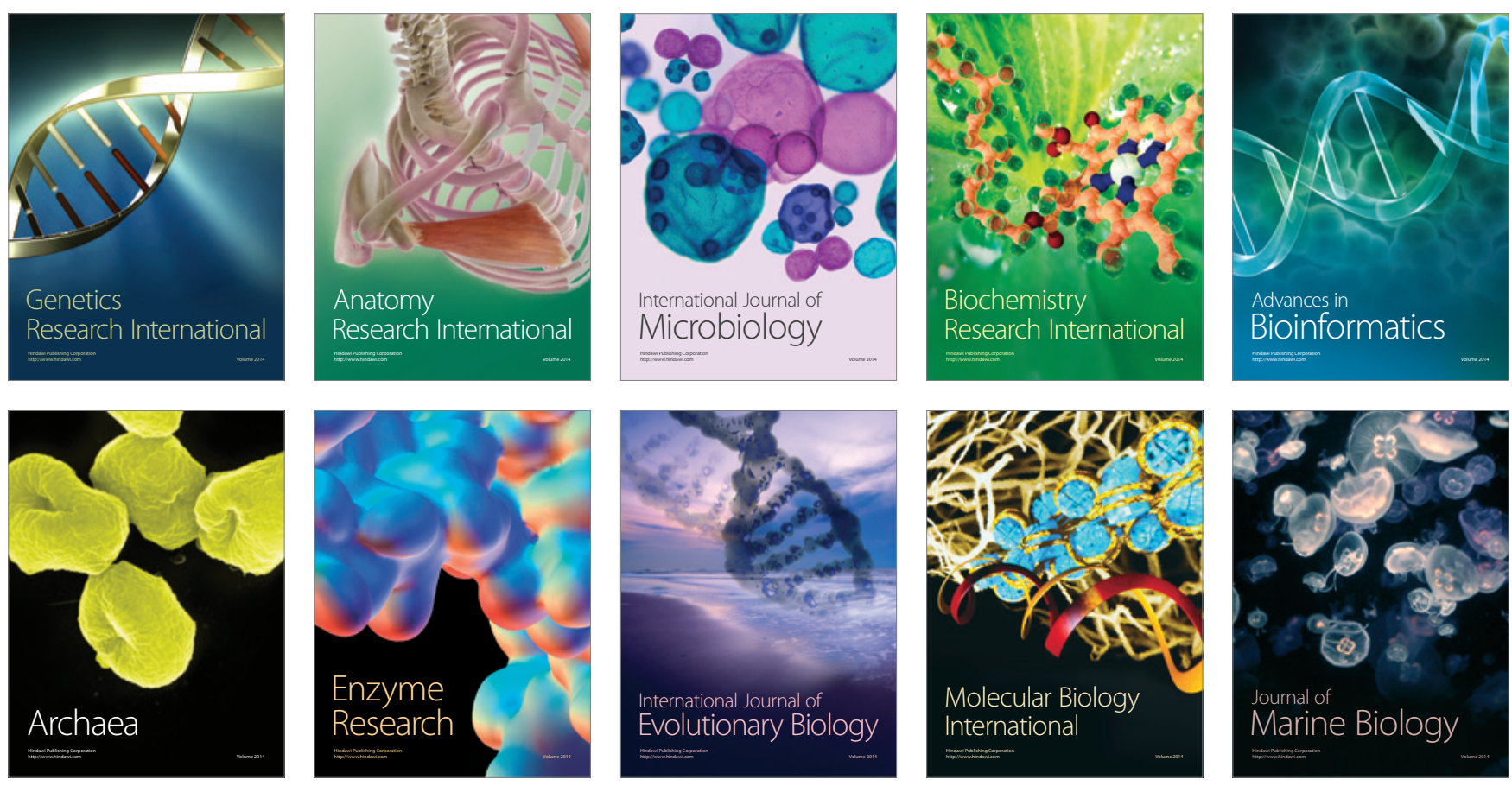